\title{
Macrophages in gastrointestinal homeostasis and inflammation
}

\author{
John R. Grainger ${ }^{1,2}$ (D) Joanne E. Konkel ${ }^{1,2}$ (D) \\ Tamsin Zangerle-Murray ${ }^{1,2}$ (D) Tovah N. Shaw ${ }^{1,2}$ (I)
}

Received: 30 January 2017 /Revised: 12 February 2017 / Accepted: 14 February 2017 / Published online: 10 March 2017

(C) The Author(s) 2017. This article is published with open access at Springerlink.com

\begin{abstract}
Monocyte-derived mononuclear phagocytes, particularly macrophages, are crucial to maintain gastrointestinal homeostasis in the steady state but are also important for protection against certain pathogens. However, when uncontrolled, they can promote immunopathology. Broadly two subsets of macrophages can be considered to perform the vast array of functions to complete these complex tasks: resident macrophages that dominate in the healthy gut and inflammation-elicited (inflammatory) macrophages that derive from circulating monocytes infiltrating inflamed tissue. Here, we discuss the features of resident and inflammatory intestinal macrophages, complexities in identifying and defining these populations and the mechanisms involved in their differentiation. In particular, focus will be placed on describing their unique ontogeny as well as local gastrointestinal signals that instruct specialisation of resident macrophages in healthy tissue. We then explore the very different roles of inflammatory macrophages and describe new data suggesting that they may be educated not only by the gut microenvironment but also by signals they receive during development in the bone marrow. Given the high degree of plasticity of gut macrophages and their multifaceted roles in both healthy and inflamed tissue, understanding the mechanisms controlling their differentiation could inform development of improved
\end{abstract}

This article is part of the special issue on macrophages in tissue homeostasis in Pflügers Archiv - European Journal of Physiology

John R. Grainger

john.grainger-2@manchester.ac.uk

1 Manchester Collaborative Centre for Inflammation Research (MCCIR), University of Manchester, Manchester M13 9NT, UK

2 Faculty of Biological, Medical and Human Sciences (FBMH), University of Manchester, Manchester, UK therapies for inflammatory diseases such as inflammatory bowel disease (IBD).

Keywords Macrophage $\cdot$ Monocyte $\cdot$ Mucosal . Gastrointestinal $\cdot$ Commensal $\cdot$ Inflammatory bowel disease

\section{Introduction}

The mammalian intestine is a complex environment for the immune system. On one hand, it must maintain tolerance to a vast array of antigens derived from food and the dense, but largely harmless, commensal microbiota. On the other, it must be ever ready to respond to potentially life-threatening pathogens that aim to colonise via the oral route. Failure to achieve this knife-edge balance between tolerance and responsiveness can lead to mortality or life-limiting morbidity, as occurs in inflammatory bowel disease (IBD).

For ongoing homeostasis to be achieved in the gut, interrelated highly specialised structural and cellular strategies have, thus, evolved to support this immunologic balancing act. All the time allowing the tissue to perform its primary physiologic function - absorption of nutrients, water and electrolytes. These structures include a mucus layer that creates a physical barrier to keep bacteria away from the epithelium, a single-cell thick epithelial layer and a specialised immune network enriched in the epithelial layer and lamina propria.

Resulting from their phagocytic capacity, functional plasticity and capability to integrate and interpret diverse foodderived, commensal-derived, pathogen-derived and hostderived signals in their environment, gut-resident macrophages are well established as a keystone immune population in barrier homeostasis in health. Moreover, following initiation of an inflammatory response, inflammation-elicited (inflammatory) macrophages (derived from circulating blood 
monocytes called into the affected tissue) in tandem with their resident partners play crucial roles in control of infection. Thus, in the face of the myriad challenges that the intestine will face over a lifetime, the dynamic regulation of the intestinal macrophage pool is at the centre of long-term health.

Macrophage biology is a field that has seen explosive growth in recent years, particularly in the gut. A large number of studies, including our work, have begun to establish how the ontogeny and differentiation of these cells is tailored by, and to, the gut environment. In this article, we will discuss these findings and particularly explore the unique mechanisms governing resident and recruited inflammatory gut macrophage function.

\section{Location and functions of resident macrophages in the healthy gut}

The largest population of resident macrophages in the body is present in the steady-state intestine $[42,56]$. They are found along the entire length of the intestine, from the proximal small intestine to the distal large intestine, and are enriched in the lamina propria (LP) close to the epithelial layer (see Fig. 1) [42]. There is also a morphologically distinct population present in the smooth muscle layers [21]. Along the length of the gut, the number of macrophages varies, with the highest density found in the colon of both humans and rodents [16, 70].

As in most tissues, a key role of macrophages in the gut is to perform housekeeping functions such as tissue remodelling and removal of senescent or dying cells $[14,70,78]$. In line with this function, they have high expression of scavenger receptors, including CD36, that are able to support apoptotic cell uptake [95]. They are also able to produce soluble factors that can help to support epithelial barrier integrity such as the lipid mediator prostaglandin $\mathrm{E}_{2}\left(\mathrm{PGE}_{2}\right)$ [25]. Additionally, macrophages located in the muscularis and serosa are important in interacting with nerves to support peristalsis, ensuring ongoing movement of ingested material along the intestine [69].

However, alongside these homeostatic functions, macrophages in the gut are also important immune sentinels and effector populations. The positioning of LP macrophages in close apposition to the epithelial layer means that they are able to rapidly uptake and respond to any material breaching this barrier [42]. These resident macrophages are highly phagocytic and have bactericidal properties [96]. They can also produce chemokines to recruit effector cells from the blood into the tissue when required [95]. Intriguingly, unlike other studied
Fig. 1 Development and functions of resident intestinal macrophages. In the healthy gut, Ly $6 \mathrm{C}^{\text {hi }}$ monocytes are constantly recruited from the blood into the gut to replenish the resident macrophage pool. Ly6 $\mathrm{C}^{\text {hi }}$ monocytes transit through a series of phenotypically defined stages to eventually become mature CX3CR $1^{\text {hi }}{ }^{\text {MHCII }}{ }^{\text {hi }}$ Ly6C ${ }^{\text {low }}$ macrophages in the lamina propria and muscularis. These macrophages are hyporesponsive to bacterial ligands, constitutively produce IL-10 and have multiple crucial functions in gut homeostasis including Treg expansion, epithelial maintenance, luminal sampling and bacterial killing

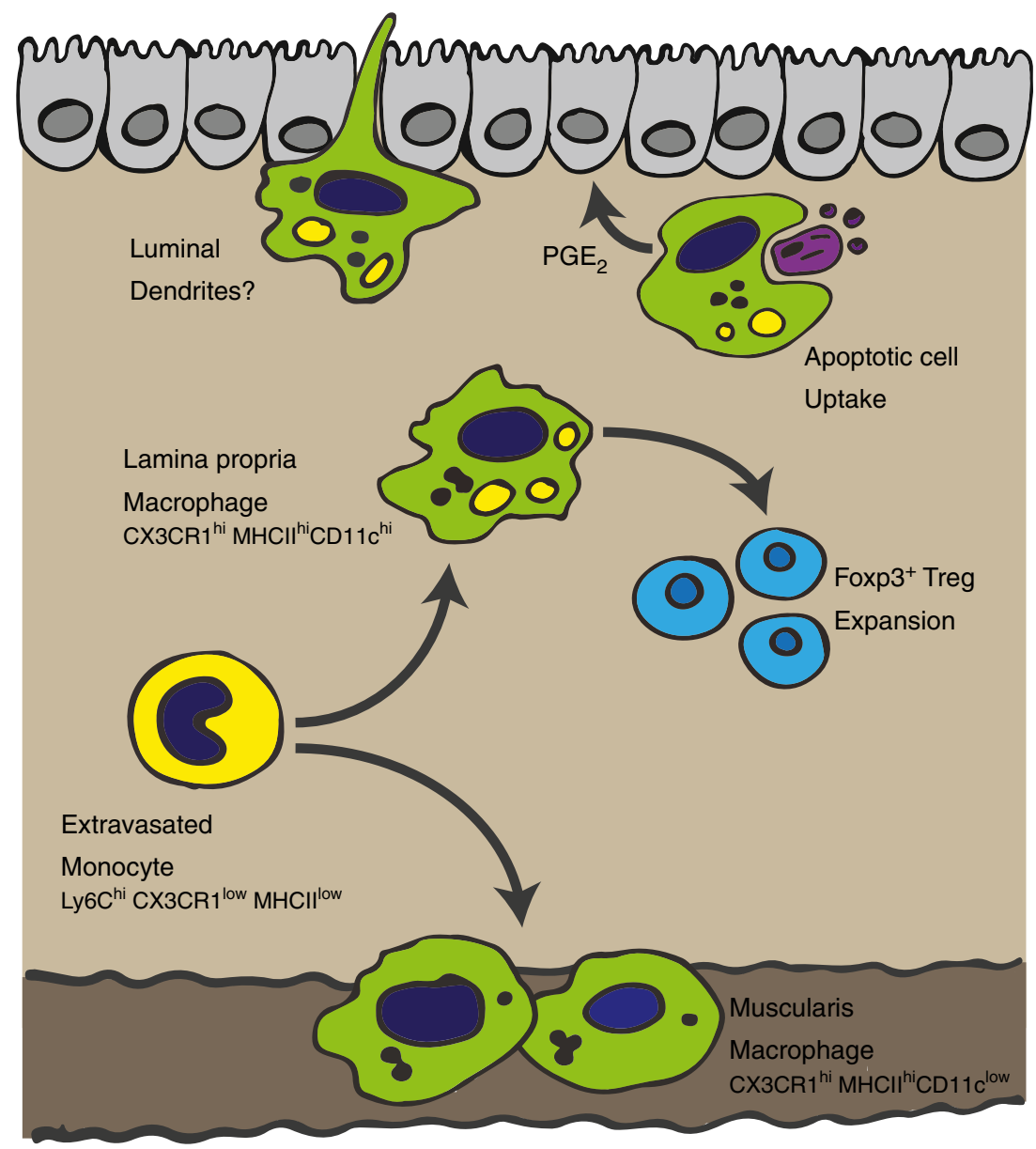


macrophage populations in the body, although gut macrophages can respond to bacteria, they do not induce classic proinflammatory responses $[4,96]$. This is a critical feature to prevent aberrant inflammation towards the high commensal bacterial load [118]. For example, ingestion of bacteria does not lead to enhanced respiratory burst activity [80], and ligation of tolllike receptors (TLRs) or nucleotide-binding oligomerisation domain (NOD)-like receptors (NLRs) does not result in increased TNF- $\alpha$ or IL-6 production $[34,96]$. Despite this hyporesponsive phenotype towards bacteria, intestinal macrophages are not completely unresponsive in their cytokine-producing capacity, and they constitutively produce the anti-inflammatory cytokine IL-10 and low levels of TNF- $\alpha$ [4]. Although this production of TNF- $\alpha$ may at first seem counterintuitive (due to its inflammatory capacity), TNF- $\alpha$ can impact enterocyte growth [61] as well as modulating production of matrix metalloproteinases from intestinal mesechymal cells [75], actions which are suggested to allow gut macrophages to support the maintenance of barrier homeostasis [3].

An important component of the gut immune system that is critical in establishing tolerance towards the high burden of food and commensal antigens is the forkhead box protein 3 $(\text { Foxp } 3)^{+} \mathrm{T}$ regulatory cell (Treg) network [65]. Since gut macrophages are able to uptake orally acquired antigens and also express high levels of major histocompatibility complex class II (MHCII) [4, 65], it is not surprising that they are suggested to play a key role in supporting development of this network. Of note, Hadis et al. demonstrated that following their priming in the lymph node, antigen-specific Foxp $3^{+}$ Tregs that had trafficked to the LP were maintained at this site by macrophages [32]. A similar role for macrophages in contributing to the tissue-resident Treg pool has also been suggested in the lung [98].

It is possible that gut macrophages may play roles in supporting maintenance of other T cell subsets in the gut. In particular, macrophages can produce IL-1 $\beta$ following TLR stimulation, and this has been suggested to support Th17 cell development in the healthy gut [93]. Along these lines, recruited macrophages have also been shown to support generation of commensal-specific Th17 cells [74]. Although gastrointestinal-resident Th17 cells are key mediators of barrier defence [113], dysregulated Th17 responses are a driver of colitogenic pathology, and in settings of gastrointestinal inflammation, macrophages have been shown to support amplification of Th17 responses [58]. Further studies will be required to establish whether macrophage education of gastrointestinal $\mathrm{T}$ cell populations requires cognate MHCII-T cell receptor interactions or whether the cytokine milieu established by macrophages is the major factor. Moreover, the influence of macrophages on other gastrointestinalresident lymphocyte populations during steady state requires further assessment, especially in the light of reports detailing macrophage-innate lymphoid cell (ILC) interactions which are key to support gastrointestinal immune homeostasis and reinforce barrier integrity $[63,68,88]$.

Another way in which gut macrophages may be able to support development of the gut $\mathrm{T}$ cell network in an indirect manner is by transfer of soluble antigen from the lumen to gut dendritic cells (DCs) [65]. These DCs then drain to the mesenteric lymph nodes to prime T cell responses [85]. It is still not entirely clear how LP macrophages acquire these luminal antigens, but one possibility is that they can extend transepithelial dendrites across the epithelium [10, 72]. However, this idea remains controversial with original reports disagreeing on which parts of the small intestine these transepithelial dendrites were present in and the necessity for TLR signalling, and subsequent studies unable to identify them $[10,51,72]$.

An issue that has confounded functional studies of gut macrophages has been the complexities of identifying this population using flow cytometry $[3,8,41]$. Initially, this problem largely arose due to the assumption that CD11c and MHCII were markers of gut DCs. In the gut, LP macrophages express high levels of CD11c as well as MHCII and thus in many studies were assumed to be DCs $[6,10]$. Unlike macrophages, DC constantly drain from tissue to lymph nodes where their major role is to prime naïve T cells [85]. More recently, the fractalkine receptor CX3CR1 has been used to distinguish gut macrophages from gut DC [6, 85, 111]. Notably, resident gut macrophages express high levels of CX3CR1; however, some subsets of gut DC also express this marker (albeit at an intermediate level), which may be the basis of more recent contradictory findings regarding DC and macrophage function [3, 8, 41].

One problem with using high expression of CX3CR1 as a marker of gut macrophages is that this can currently only be established using CX3CR1-GFP transgenic mice and not by antibody staining [46]. A more useful strategy for identifying gut macrophages by multicolour flow cytometry (that can be used in non CX3CR1-GFP expressing animals) came from large-scale genomic datasets alongside more targeted studies [2, 4, 23, 104]. Together, these publications have identified that CD64 (Fc $\gamma \mathrm{RI}$ ), F4/80 and MHCII used in combination with Ly6C and lineage exclusion markers (e.g. for lymphocytes and granulocytes) can reliably define these cells. CD11c expression was found to be of particular relevance to distinguish LP macrophages $\left(\mathrm{CD} 11 \mathrm{c}^{\mathrm{hi}}\right)$ from those in the serosa and muscularis (CD11 $c^{\text {low }}$ ) [6]. When isolated by fluorescenceactivated cell sorting (FACS), these cells exhibit characteristic macrophage morphology and cannot be found draining to the mesenteric lymph nodes [2, 41]. Moreover, their development is critically dependent on colony stimulating factor 1 receptor (CSF1R) (also known as macrophage colony-stimulating factor receptor (MCSFR)) [82, 83] but independent of the DC growth factor FMS-like tyrosine kinase 3 ligand (FLT3L) [104]. Altogether, these findings suggest that CD64 and F4/ 
80 are bona fide markers of gut-resident macrophages and will support researchers in specifically determining gut macrophage functions in future studies.

\section{The unusual ontogeny of resident gut macrophages}

When the mononuclear phagocyte system (MPS) was first described just over 50 years ago, it was proposed that tissue macrophages were the terminal differentiation stage of blood monocytes after recruitment into tissue [110]. However, in more recent years, a number of studies have been published that demonstrate that the majority of tissue macrophages are able to exist independently of blood monocyte precursors [33, $38,39]$. Frequently these derive from foetal liver precursors although some, including the microglia of the central nervous system (CNS), come from the yolk sac [24, 38, 39, 116]. These cells seed tissues prenatally and then are maintained by local proliferation. Resident macrophages include those of the lung alveoli [116], the Kuppfer cells of the liver [87] and epidermal Langerhans cells [39].

The adult intestinal macrophage pool is a major exception to this rule (along with the dermis [103] and more controversially the heart $[18,66])$ fitting the original MPS model, requiring constant replenishment from blood monocytes (see Fig. 1) [2, 4, 6, 119]. Blood monocytes are a heterogeneous circulating population in both humans and mice that originate in the bone marrow (BM). In mice, there is a subset that expresses high levels of Ly6C and CCR2 termed "classical" monocytes (the equivalent of human CD14 ${ }^{\text {hi }}$ monocytes [43]) that are the precursors to the adult intestinal macrophages $[2$, 4, 6, 119]. Although at birth, there are embryonically derived macrophages present in the gut, around the time of weaning these are replaced by cells derived from an influx of CCR2dependent Ly6 $\mathrm{C}^{\text {hi }}$ monocytes [2].

A number of studies investigating macrophage differentiation in the healthy gut have been instrumental in defining the phenotypic and transcriptional profile of classical (Ly6C ${ }^{\text {hi }}$ ) blood monocytes transitioning into mature gut macrophages. Initially using an adoptive transfer approach in healthy gut, it was shown that Ly6C $\mathrm{C}^{\text {hi }}$ monocytes were able to enter into the colon and mature into $\mathrm{CD} 64^{+} \mathrm{F} 4 / 80^{\mathrm{hi}} \mathrm{CX} 3 \mathrm{CR} 1{ }^{\mathrm{hi}} \mathrm{MHCII}^{+}$macrophages [4]. This developmental process involves a series of identifiable intermediaries in which Ly6C expression is lost while expression of F4/80, CX3CR1, CD163 and CD206 are gained. Due to the visual appearance of this transition moving from $\mathrm{Ly}_{6 \mathrm{C}}{ }^{\text {hi }}$ to $\mathrm{MHCII}{ }^{\mathrm{hi}}$ or $\mathrm{CX} 3 \mathrm{CR} 1^{\text {hi }}$ on a flow cytometry plot, this has been referred to as the monocyte to macrophage "waterfall" [2, 104]. Differentiation takes approximately 5 days and results in a cell that has increased phagocytic capacity and constitutive IL-10 production and is anergic to TLR stimulation. This rapid differentiation is in line with earlier reports of an approximately 3-5-week half-life for gut-resident macrophages [45]. Although the precise mechanisms governing differentiation cannot be easily established in humans, resident gut macrophages deriving from blood monocytes is implied by a similar waterfall of CD14 ${ }^{\mathrm{hi}}$ (marker characteristic of classical monocytes [43]) to $\mathrm{CD} 14^{\text {low }} \mathrm{CD} 209^{\text {hi }} \mathrm{CD} 163^{\text {hi }}$ cells [4].

The complex commensal flora is a distinguishing feature of the intestine, and there is a current consensus that it is this feature that is important in regulating the continuous replenishment of resident gut macrophages from blood monocytes $[2,3,118]$. Of note, there is a first accumulation of colonic macrophages between 2 and 3 weeks of age in mice that is concurrent with increased commensal colonisation [2]. Corroborating the importance of the microbiome in this process, at 3 weeks of age, there were fewer mature macrophages in germ-free mice than conventionally housed controls. Moreover, many of these macrophages did not express MHCII further implicating the microbiome in typical differentiation of macrophages as well as recruitment [4, 119].

It is worth noting, however, that this was not the first study to investigate colonic macrophage abundancy in germ-free animals, and these studies have reached opposing conclusions [71, 79, 108]. Animals from different sources are now well known to have very different commensal composition [11, 44, 107]. One hypothesis for these differences between studies is that there are unique factors in the gut other than the microbiome that can affect macrophage replacement from blood monocytes but that specific bacterial species present in certain mouse colonies can enhance or decrease the turnover rate.

Taken together, the studies to date strongly suggest that in both mice and humans, and in stark contrast to other tissues, resident gut macrophages are continuously replenished from circulating blood monocytes. Whether this information can be used to design strategies to specifically target gut macrophages remains to be explored but suggests that they may be impacted by systemic drug administration in a way that macrophages maintained locally in tissue would not.

\section{Instruction of resident gut macrophage function}

The main cues present in the gut environment that are responsible for monocyte to resident macrophage differentiation are still poorly defined. However, it is likely that there are specific signals or combinations of signals in the gut that induce characteristics not observed at other mucosal sites such as the skin and lung [55, 86, 103, 109].

There are a number of important growth factors involved in the establishment of the MPS, notably, FLT3L, CSF1 (MCSF) and CSF2 (granulocyte macrophage colony-stimulating factor). Although FLT3L and CSF2 may have impacts on gut macrophage function [68], they appear to be dispensable for their development $[26,104]$. This is in stark contrast to lung 
macrophages for which CSF2 signalling is extremely important $[30,101]$. Two ligands have been identified for CSF1R: CSF1 itself and IL-34 [112]. It seems most likely that development and maintenance of macrophages in the gut are CSF1 dependent as there is a marked reduction of macrophages in mice that have a mutation in the gene that encodes CSF1 $\left(C s f 1^{o p / o p}\right)$ or following administration of anti-CSF1R antibody $[69,82]$.

One particularly unusual phenotype of resident gut macrophages is their acquisition of high levels of CX3CR1 expression. In the majority of tissues, CX3CR1 is downregulated on macrophages suggesting that there is a factor in the gut responsible for its continued expression. A recent study has suggested that TGF- $\beta$, which is established to induce CX3CR1 expression in the brain [9], is also a dominant signal for CX3CR1 expression by gut macrophages [84]. This is in line with the identification of Runx 3 as a characteristic transcription factor of gut macrophages that is regulated by TGF- $\beta$ in T cells $[52,53,55]$. In addition, it is possible that the interaction of CX3CR1 with CX3CL1 (fractalkine) may be important itself in instructing gut macrophage function. For example, it has been suggested that CX3CR1-CX3CL1 interactions are critical for optimal production of IL-10 by macrophages [32].

IL-10 signalling is one pathway that has been shown to be crucial for instructing macrophage function in the gastrointestinal (GI) mucosa $[94,117]$. Not only do macrophages make IL-10, but IL-10 signals to the macrophage are vital for the appropriate education of intestinal macrophage populations, providing a key cue that safeguards their hyporesponsive phenotype (discussed below). It has long been known that in the absence of IL-10, severe gastrointestinal inflammation results [54]; what is now clear is that IL-10 receptor signalling on macrophages, but not the production of IL-10 itself, is key in restraining this inflammation $[94,117]$. When unable to respond to IL-10, gut macrophages produce increased levels of inflammatory cytokines in response to bacterial stimulation $[102,108]$ and drive development of colitis [40]. More recently, specific deletion of IL-10R $\alpha$ on CX3CR1-expressing gut macrophages was shown to lead to the development of a spontaneous, and severe, ulcerative colitis-like GI inflammation [117]. Part of this IL-10 conditioning of macrophage function has been reported to include limiting levels of NOS2, $\mathrm{PGE}_{2}$, IL-23 [117], inflammasome components and pro-IL-1 $\beta$ [19, $31,58]$. Thus, IL-10 signals have emerged as a vital restraint against overt macrophage activation. Interestingly, this pathway has also been implicated in early onset IBD, as similar functional alterations to those seen in animal models have been observed in patients with IL-10R mutations [94].

As mentioned, another key feature of gut macrophages is their apparent hyporesponsiveness to TLR-mediated activation. Intriguingly, gut-resident macrophages both in humans and mice express a full repertoire of TLR receptors, so it is thought that it is downstream mediators that are responsible for the hyporesponsiveness [4, 97]. Of note, molecules including MyD88, TRAF-6, TRIF and CD14 are downregulated in mature macrophages $[96,97,119]$. Additionally, there may be alternative pathways that impair TLR responsiveness, for example, through increased expression of IRAK-M and IKBNS [37, 97, 119].

An emerging mediator of gut macrophage function is neuroendocrine signals, controlling macrophage survival and phenotype within the highly innervated gastrointestinal mucosa. Neuronal-macrophage interactions are bidirectional with macrophages in the muscularis capable of controlling peristaltic activity. Bone morphogenetic protein 2 (BMP2), produced by macrophages, acts on enteric neurons to control smooth muscle contractions and thus, peristalsis [69]. In return, neuroendocrine signals to macrophages support maintenance of macrophage populations within specific gastrointestinal niches. Bogunovic and colleagues demonstrated that enteric neurons ensure maintenance of macrophages specifically within the muscularis layer of the gastrointestinal tract through production of CSF1 [69] (as discussed a key growth factor in gut macrophage development). This neuroendocrine control of macrophage survival was downstream of commensal bacteria colonisation as microbial-derived signals promoted enteric neuron expression of CSF1. Additional macrophage niche specialisation by neuroendocrine pathways can also be driven by norepinephrine signals from sympathetic neurons. Muscarlis macrophages express $\beta 2$ adrenergic receptors that, upon binding of norepinephrine released from local active neurons, promote acquisition of a tissue-protective programme in muscularis-resident macrophages during infection [21].

Intriguingly, and in line with microbial activation of CSF1 production from enteric neurones [69], it has also been reported that the microbiota controls glial cell homeostasis in the intestine [47]. These supporting cells provide key maintenance and protection for neurons further highlighting the complex integration of microbial, endocrine and immune signals in controlling GI immune homeostasis and inflammation. The very recent focus on neuroendocrine signals in control of immune cell function within the gut [64] will likely yield further insights into tissue training of macrophage function by these signals.

In addition to the signals described, there are many other factors expressed in the gut environment that may play important roles on macrophages but as yet have been poorly explored. These factors include thymic stromal lymphopoietin (TSLP), the mucus layer itself that has been shown to modify DC function [92] and retinoic acid. Retinoic acid is particularly intriguing as it is known to have profound effects on DC in the gut and in tandem with TGF- $\beta$ support induction of Treg $[12,100]$. The impact of RA on macrophages has yet to be precisely elucidated. 
Inflammatory gut macrophages in experimental settings of classical inflammation

Infiltration of classical $\left(\mathrm{Ly} 6 \mathrm{C}^{\text {hi }}\right)$ monocytes that differentiate rapidly into effector cells is a common feature following intestinal damage and infection of mice [4, 25, 104, 119] (see Fig. 2). Perhaps the best-studied murine models of this are colitis induced by administration of dextran sodium sulphate (DSS) and T cell transfer colitis [4, 104, 119]. In both of these settings, there is a characteristic reversal in the composition of the macrophage compartment. In particular, CX3CR $1^{\text {hi }}$-resident gut macrophages that dominate in the healthy gut are outcompeted by inflammation-elicited CX3CR $1^{\text {int }}$ mononuclear phagocytes (MNPs) that are the progeny of rapidly infiltrating Ly6C ${ }^{\text {hi }}$ monocytes [4, 119]. Precise definitions of the functions of this MNP pool are complex, and the cells within this pool are on a differentiation spectrum that likely includes populations with more macrophage-like or DC-like functions [119]. For the rest of this review, focus will be placed on the macrophage-like features of these cells that are present in inflammation that for clarity will be referred to as inflammatory macrophages (although the reader should note, and as will be discussed, that their functional and differentiation potential as well as morphology is very different to resident gut macrophages). These cells have a strong pro-inflammatory signature characterised by the production of factors including TNF- $\alpha$, IL-1 $\beta$, IL- 6 and inducible nitric oxide synthase (iNOS). Of note, despite their presence in this proinflammatory milieu, the resident $\mathrm{CX} 3 \mathrm{CR} 1^{\mathrm{hi}}$ macrophages continue to maintain the largely anti-inflammatory characteristics they exhibit in health [4, 104, 114, 119]. Not surprisingly, given their pro-inflammatory features, there is strong evidence for a pathologic role for the CX3CR $1^{\text {int }}$ macrophages in these murine models of colitis. For example, in $\mathrm{Ccr} 2^{-/-}$mice (which have a paucity of monocytederived cells in circulation and tissues due to a failure in classical monocyte release from the bone marrow [89]), or animals depleted of CCR2-expressing cells [119], there is an amelioration of DSS-driven colitic inflammation.

One intriguing feature of the Ly6 $\mathrm{C}^{\text {hi }}$ monocyte differentiation pathway to inflammatory macrophages during colitis is the apparent concurrent impairment in Ly6 $\mathrm{C}^{\text {hi }}$ monocyte
Fig. 2 Macrophages during gut inflammation. Following epithelial damage or pathogen invasion, classical monocyte-derived effector cells are elicited and enter the now inflamed GI tract. The functions of these populations are poorly defined but likely highly specialised to the precise challenge and may include DC-like activities. Many differentiate into macrophages that are crucial for pathogen control but can also lead to pathology as a result of their potential to produce inflammatory cytokines such as TNF- $\alpha$. During $T$. gondii infection, these cells also take on the capacity to suppress neutrophil activation via release of $\mathrm{PGE}_{2}$. Of note, during T. gondii infection, instruction of macrophage function begins in the bone marrow resulting in monocytes entering the tissue in a primed state characterised by their low expression of CX3CR1 and high expression of MHCII. Although monocytes no longer differentiate to resident macrophages (CX3CR1 ${ }^{\text {hi }}$ lamina propria and muscularis macrophages) during inflammation, those present prior to barrier breach remain in the tissue and continue to exhibit antiinflammatory features

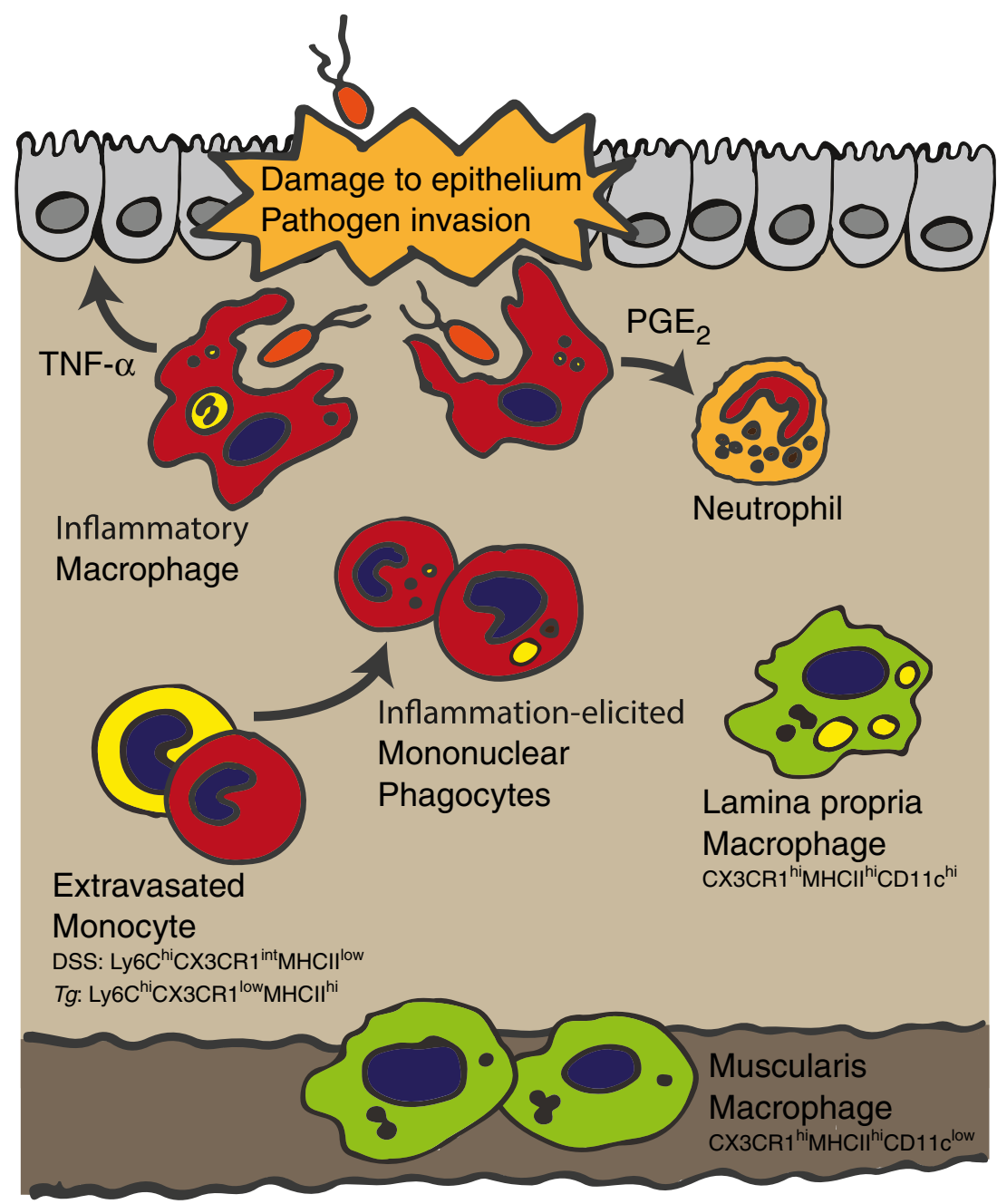


differentiation to resident $\mathrm{CX} 3 \mathrm{CR} 1^{\text {hi }}$ macrophages $[4,104$, 119]. Indeed, it has been proposed that this arrest in the differentiation pathway may underlie the ongoing capacity of inflammatory macrophages to respond to TLR stimulation in DSS colitis. The precise mechanisms that result in such changes are currently unknown but are likely due to signals being altered in the local microenvironment that are critical for educating monocytes to become resident anti-inflammatory macrophages.

Despite inflammatory macrophages playing immuno pathogenic roles during acute colitic-like inflammation, in certain gastrointestinal infections, they are crucial for pathogen protection $[17,25]$. Following oral inoculation with the highly type 1 polarising intracellular protozoan parasite Toxoplasma gondii, there is dramatic infiltration of Ly6 $6 \mathrm{C}^{\text {hi }}$ monocytes into the inflamed small intestine [17, 25]. Once again, the importance of monocytes in this setting can be revealed by the fact that CCR2-deficient mice or those deficient in its ligand CCL2 fail to control the parasite [17, 25], and this can be restored by monocyte transfer [17].

Although, this parasite control was initially attributed to the capacity of recently recruited macrophages to produce proinflammatory cytokines such as TNF- $\alpha$ and iNOS, their function has since been revealed to be more complex [25]. Our studies demonstrated that in CCR2-deficient animals infected with $T$. gondii, neutrophils became hyperactivated in the lamina propria of the gut where they produced dramatically increased levels of tissue damaging factors including TNF- $\alpha$ and reactive oxygen species (ROS) [25]. This was associated with increased severity of gastrointestinal pathology that was independent of increases in parasite load. Immunofluorescent imaging revealed that Ly6 $\mathrm{C}^{\text {hi }}$ inflammatory macrophages localised closely with neutrophils in the inflamed gut suggesting that one explanation for their enhanced activity might be direct suppressive actions of Ly6C ${ }^{\text {hi }}$ macrophages. Supporting this idea, we found that treatment of neutrophils with factors released from Ly6 $\mathrm{C}^{\text {hi }}$ macrophages isolated from T. gondiiinfected guts limited the neutrophils' capacity to produce pro-inflammatory factors in response to TLR ligands and formyl peptides. Further experiments revealed that this effect was entirely dependent on the release of the lipid mediator $\mathrm{PGE}_{2}$, which is highly expressed by inflammatory macrophages during $T$. gondii infection $[1,25]$ (see Fig. 2). This lipid mediator can have complex and opposing roles over the course of an inflammatory response as it can favour inflammatory cell recruitment [48] but is also a potent suppressor of human neutrophil activation [115].

Following its initial invasion of the gut, $T$. gondii infection eventually disseminates systemically and inflammatory macrophages infiltrate lymphoid tissues including the spleen [25]. However, the neutrophil-suppressive activity was only evident in macrophages isolated from the gut. Studies using germ-free (GF) mice revealed that this was critically dependent on commensal-derived ligands.
The precise bacteria involved in instructing macrophage function during inflammation are likely very different to those resident macrophages are exposed to in health. Notably, in the context of gut infection, there is tremendous outgrowth of potentially pathogenic commensal populations, specifically $\gamma$-proteobacteria such as Escherichia coli [35, 67]. Outgrowth of $\gamma$ proteobacteria has also been reported in patients with IBD $[15,59]$. Indeed, in vitro treatment of circulating Ly6 $\mathrm{C}^{\text {hi }}$ monocytes from the blood of $T$. gondii-infected animals with a lysate from a commensal form of $E$. coli led to rapid $\mathrm{PGE}_{2}$ production. Of course, in vivo, there may be additional gut-specific signals responsible for initiating $\mathrm{PGE}_{2}$ release. For example, stimulated epithelial cells can produce and activate IL-1 $\beta$ [99], a strong driver of $\mathrm{PGE}_{2}$ from macrophages [76], and commensal-derived dietary ligands such as short chain fatty acids (SCFAs) can also augment $\mathrm{PGE}_{2}$ production [13]. It is interesting to speculate that in certain individuals or at defined time points during infection, alterations in the composition of commensal species may be able to favour acquisition of regulatory features by infiltrating monocytes.

Another mechanism by which inflammatory macrophages may act to suppress immune cells during inflammation is via actions on $\mathrm{T}$ cells. This could be achieved by modifying Larginine metabolism, as nitric oxide (NO) limits T cell proliferation [5]. Inflammatory macrophages in the GI tract during acute infection and inflammation have been shown to be positive for this immune mediator. In the spleen, during Listeria monocytogenes infection, $\mathrm{iNOS}^{+}$macrophages suppress antigen-specific T cell responses [90]. Given the prevalence of iNOS $^{+}$macrophages in the GI tract during inflammation, these data imply that these cells may well be capable of suppressing effector $\mathrm{T}$ cell responses in the GI mucosa. In line with this, a CX3CR $1^{+} \mathrm{CD} 11 \mathrm{c}^{+} \mathrm{CD} 11 \mathrm{~b}^{+} \mathrm{MNP}$ in the GI tract has been shown to be capable of limiting $\mathrm{CD}^{+} \mathrm{T}$ cell proliferation [50]. This required cell-cell contact highlighting another mechanism that could be employed by macrophages to curtail gastrointestinal $\mathrm{T}$ cell responses.

\section{Macrophages in human gut inflammation}

Mechanistic understanding of macrophages in human gut inflammation is much more limited than in animal models. One thing that is clear is that CD14 $4^{\text {hi }} \mathrm{MNP}$ accumulate in the inflamed gut in settings such as IBD [49], likely in response to elevated levels of the chemokines CCL2 and CCL4 [95]. Indeed, by radiolabelling of autologous blood monocytes, it was demonstrated that the $\mathrm{CD} 14^{\mathrm{hi}}$ cells arise from these circulating precursors [27]. These cells are the human equivalent of the Ly6 $\mathrm{C}^{\text {hi }}$ populations in mice that become dominant during induced colitis and oral $T$. gondii infection $[4,17,25,104$, 
119]. As with recruited macrophages in the mouse, the CD14 ${ }^{\text {hi }}$ cells in the inflamed human intestine produce high levels of TNF- $\alpha$, IL-1 $\beta$ and IL-6 [81] and have ongoing responsiveness to microbe-derived factors $[49,105]$.

In addition to cytokine release, it has also been reported that macrophages in the inflamed mucosa have increased expression of CD40 that may support local interactions with pathology-driving effector $\mathrm{T}$ cells [7], again mirroring data from murine models [119]. Given the currently sparse data on human intestinal macrophage function, but their high relevance to disease pathology, this will no doubt be an area for tremendous future scientific study. The already strong similarities between patient samples and murine models suggest that integration of these two investigative strategies may be key to rapidly progressing our knowledge of this area.

\section{Long-range instruction of inflammatory gut macrophage function during infection}

At steady state, much research focus has been placed on the cues present in the gut environment that locally instruct resident gut macrophage differentiation. Based on this model, during gut inflammation, factors at the affected tissue site to which infection-elicited macrophages are exposed have been of primary interest. However, a number of recent findings, including those from our group, suggest that a more holistic approach to understanding macrophage differentiation during inflammation needs to be employed.

It is well established that when stressed, tissues such as the gut can send signals to the bone marrow (BM) niche and blood to improve supply of required circulating immune populations $[28,89]$. We found that during gut infection, these long-range signals can also instruct for altered functional potential. As early as 4 days after oral infection with $T$. gondii, Ly6 $\mathrm{C}^{\text {hi }}$ monocytes developing in the $\mathrm{BM}$ niche acquired a characteristic CX3CR $1{ }^{\text {low }} \mathrm{MHCII}{ }^{\mathrm{hi}} \mathrm{Sca}-1{ }^{\mathrm{hi}}$ phenotype, which was also observed in inflammatory gut macrophages [1] suggesting that instruction of eventual macrophage differentiation may be beginning in the BM. Most importantly, when highly pure BM Ly6 $\mathrm{C}^{\text {hi }}$ monocytes were isolated by FACS from naïve and T. gondii-infected animals and exposed to commensal signals they ultimately would experience in the inflamed gut, they already had enhanced capacity to produce $\mathrm{PGE}_{2}$ prior to BM efflux. As discussed already, we have established $\mathrm{PGE}_{2}$ as a critical recruited gut macrophage-derived factor regulating neutrophil-mediated immunopathology during oral T. gondii infection [25]. Thus, during gut infection, functional priming of inflammatory macrophages can begin in the BM.

Although $\mathrm{PGE}_{2}$ production was highlighted, the $\mathrm{Ly} 6 \mathrm{C}^{\text {hi }}$ monocytes had profound transcriptional changes and also had enhanced capacity to produce anti-inflammatory IL-10 in response to bacterial ligands. These transcriptional changes were at least initiated in the direct proliferative precursor to monocytes, the common monocyte progenitor (cMoP) [36], but earlier progenitors such as the MDP were not investigated due to issues of identification in infection [1].

The precise mechanisms that the gut can use to communicate to the BM niche are not understood. During T. gondii infection, we identified a whole organism signalling loop in which a specific subset of gut $\mathrm{DC}\left(\mathrm{Batf}^{+}\right)$released the cytokine IL-12 in the serum that was detected by a subset of mature natural killer (NK) cells present in the BM. These NK cells produced IFN- $\gamma$ locally in the BM in response to the IL12 signal, which was critical in generating the high $\mathrm{PGE}_{2}-$ producing CX3CR $1{ }^{\text {low }} \mathrm{MHCII}{ }^{\mathrm{hi}} \mathrm{Sca}-1^{\mathrm{hi}}$ monocytes. Although IFN- $\gamma$ was a dominant signal, whether additional signals in the BM environment are also altered following $T$. gondii infection and whether these have specific functional effects on developing monocytes and eventually their gut macrophage progeny remain unknown. One possibility is food-derived ligands such as short-chain fatty acids (SCFAs), as these have previously been shown to modify DC function prior to exit from the BM in an asthma model [106].

Intriguingly, during $T$. gondii infection, our data suggested that perturbations to monocyte-macrophage differentiation capacity might be initiated systemically, as there were dramatic increases in circulating Ly6 $\mathrm{C}^{\text {hi }}$ monocytes with a concurrent loss of Ly $6 \mathrm{C}^{\text {low }}$ patrolling monocytes (which are suggested to derive from the Ly6 $\mathrm{C}^{\text {hi }}$ population [116]). This bears striking similarity to the proposed block in differentiation of monocytes to resident gut macrophages in colitis $[4,119]$. The cytokine IFN- $\gamma$ was implicated in this process [1], but further work will be needed to confirm whether this is due to an arrest in normal differentiation pathways (rather than, for example, increased BM output of $\mathrm{Ly} 6 \mathrm{C}^{\text {hi }}$ monocytes) and whether these Ly $6 \mathrm{C}^{\text {hi }}$ monocytes are also unable to differentiate into resident macrophages upon entry into the gut.

\section{Resident and inflammatory macrophages in resolution of inflammation}

Once the infection, or other inflammation-driving factor, has been cleared or becomes tolerated in the gut, there must be a resolution phase to restore homeostasis. If this does not happen, then chronic inflammation may develop.

As occurs during inflammation, this resolution phase is also associated with striking alterations to gut macrophage subsets. One example of this is that following resolution of DSS colitis in mice, the augmented CX3CR $1^{\text {int }}$ MNP subset returns to baseline levels [119]. Precise reasons for the loss of the CX3CR $1^{\text {int }}$ subset are not known, but apoptosis and uptake by resident macrophages seem probable [22]. An alternative possibility, based on the idea that $\mathrm{CX} 3 \mathrm{CR} 1{ }^{\text {int }}$ cells are blocked in their differentiation to resident gut macrophages during inflammation, is that due to alterations in the cytokine milieu, this limitation is removed. As a result, many of the 
CX3CR 1 int cells would "disappear" from the gut by differentiating into resident gut macrophages.

Whatever the case, it seems that gut monocytes/macrophages are important in gut repair and resolution of inflammation. In particular, there is a delay in DSS colitis resolution in animals that lack TGF- $\beta$ signalling on monocytes/macrophages (CD68dnTGF $\beta$ RII) [78], while deletion of MyD88 signalling in myeloid cells limits gut healing [62].

Although not well studied specifically in the gut, one set of factors that are important in restoration of homeostasis in all tissues are pro-resolving lipid mediators [91]. These factors, as well as limiting influx of additional inflammatory cells, can promote the uptake of apoptotic cells by macrophages [20, 29]. Types of lipid mediators include lipoxins, resolvins and protectins that can be produced by multiple cell types including macrophages [91]. One factor that has been demonstrated to favour production of lipoxins is prostaglandins, in particular $\mathrm{PGE}_{2}$. For example, in resolving inflammatory exudates, it has been suggested that $\mathrm{PGE}_{2}$ and $\mathrm{PGD}_{2}$ can stimulate production of a functional enzyme for lipoxin in neutrophils [57]. Based on our studies in T. gondii infection, this raises the intriguing possibility that Ly6 $\mathrm{C}^{\mathrm{hi}}$ monocytes/macrophages not only limit neutrophil activation but also deviate their function towards a lipoxin-producing pro-resolution state. Relating to this, macrophages may also be able to regulate wound healing directly by interacting with epithelial progenitor cells during colonic wound healing [77]. Again, lipid mediators may play a role in this process as COX-2 expression, a critical factor in $\mathrm{PGE}_{2}$ production, has been linked to protection of progenitor populations at other tissue sites during inflammation [60].

As well as repairing the barrier, another feature of return to homeostasis is the restoration of the adaptive immune compartment, which can become dramatically perturbed during an inflammatory response [73]. At this time, it is unclear how the mononuclear phagocytes of the gut may act together to support this return, but given their suggested role in expanding Tregs at steady state, it is likely that gut-resident macrophages are important to this process.

With the recent advances in technologies for the generation of transgenic murine systems, novel tools for the temporal knockout of specific genes in defined macrophage/monocyte subsets are likely to become increasingly available. This will allow candidate factors identified as being important to resolution to be depleted during this phase of the inflammatory response without impairing initiation of disease. Already, the tamoxifen-inducible Cx3CR $1^{\text {creER }}$ mouse that knocks out factors in CX3CR $1^{\text {hi }}$-resident gut macrophages holds much promise for this purpose [116].

\section{Concluding remarks}

Utilising novel transgenic animals alongside cutting-edge cytometric and genomic approaches, recent years have seen an explosion in our understanding of macrophage biology in general and more specifically in the gut. In particular, the field is beginning to better define the diverse functions that these cells play in tissue homeostasis and how they can be manipulated in disease states.

With the advent of single-cell RNA sequencing, it will become more straightforward to define functionally distinct macrophage subsets within complex and potentially inflamed tissue environments. One aspect of macrophage biology that has been largely overlooked in recent years is precise localisation within the tissue. For example, in the gastrointestinal tract, there are diverse structural components to the tissue, e.g. muscle, nerves, blood vessels and epithelium. How macrophage function might be tailored to each of these niches is only just beginning to be understood.

Another area in the functional diversity arena is to further understand the differential roles of resident macrophages versus inflammatory macrophages in disease states. It is clear that resident macrophages are often maintained in the inflammatory environment but are not acquiring classical activation markers. Whether these cells play a role during the active inflammatory event or in restoring homeostasis post challenge is extremely unclear. This is critical to understand as it would help elucidate specific macrophage factors that can be manipulated at defined time points in the inflammation resolution cycle to alter outcome.

Whatever the future of macrophage research holds, given the importance of intestinal macrophages to the maintenance of homeostasis and disease progression, better understanding the development and functions of this cell type will no doubt yield novel strategies that can inform development of therapies to improve patient outcome in inflammatory diseases such as IBD.

Acknowledgements Funding is provided to J.R.G. through a Sir Henry Dale Fellowship jointly supported by The Wellcome Trust and The Royal Society (104195/Z/14/Z) and by a Manchester Collaborative Centre for Inflammation Research grant. J.E.K. is supported by a BBSRC-funded Sir David Phillips Fellowship (BB/M025977/1) and by a Manchester Collaborative Centre for Inflammation Research grant.

\section{Compliance with ethical standards}

Conflict of interest The authors declare that they have no conflict of interest.

Open Access This article is distributed under the terms of the Creative Commons Attribution 4.0 International License (http:// creativecommons.org/licenses/by/4.0/), which permits unrestricted use, distribution, and reproduction in any medium, provided you give appropriate credit to the original author(s) and the source, provide a link to the Creative Commons license, and indicate if changes were made.

\section{References}

1. Askenase MH, Han SJ, Byrd AL, Morais da Fonseca D, Bouladoux N, Wilhelm C, Konkel JE, Hand TW, LacerdaQueiroz N, Su XZ, Trinchieri G, Grainger JR, Belkaid Y (2015) 
Bone-marrow-resident NK cells prime monocytes for regulatory function during infection. Immunity 42:1130-1142

2. Bain CC, Bravo-Blas A, Scott CL, Gomez Perdiguero E, Geissmann F, Henri S, Malissen B, Osborne LC, Artis D, Mowat AM (2014) Constant replenishment from circulating monocytes maintains the macrophage pool in the intestine of adult mice. Nat Immunol 15:929-937

3. Bain CC, Mowat AM (2014) Macrophages in intestinal homeostasis and inflammation. Immunol Rev 260:102-117

4. Bain CC, Scott CL, Uronen-Hansson H, Gudjonsson S, Jansson O, Grip O, Guilliams M, Malissen B, Agace WW, Mowat AM (2013) Resident and pro-inflammatory macrophages in the colon represent alternative context-dependent fates of the same Ly6Chi monocyte precursors. Mucosal Immunol 6:498-510

5. Bogdan C (2001) Nitric oxide and the immune response. Nat Immunol 2:907-916

6. Bogunovic M, Ginhoux F, Helft J, Shang L, Hashimoto D, Greter M, Liu K, Jakubzick C, Ingersoll MA, Leboeuf M, Stanley ER, Nussenzweig M, Lira SA, Randolph GJ, Merad M (2009) Origin of the lamina propria dendritic cell network. Immunity 31:513525

7. Carlsen HS, Yamanaka T, Scott H, Rugtveit J, Brandtzaeg P (2006) The proportion of CD40+ mucosal macrophages is increased in inflammatory bowel disease whereas CD40 ligand (CD154)+ T cells are relatively decreased, suggesting differential modulation of these costimulatory molecules in human gut lamina propria. Inflamm Bowel Dis 12:1013-1024

8. Cerovic V, Bain CC, Mowat AM, Milling SW (2014) Intestinal macrophages and dendritic cells: what's the difference? Trends Immunol 35:270-277

9. Chen S, Luo D, Streit WJ, Harrison JK (2002) TGF-beta1 upregulates CX3CR1 expression and inhibits fractalkinestimulated signaling in rat microglia. J Neuroimmunol 133:46-55

10. Chieppa M, Rescigno M, Huang AY, Germain RN (2006) Dynamic imaging of dendritic cell extension into the small bowel lumen in response to epithelial cell TLR engagement. J Exp Med 203:2841-2852

11. Chudnovskiy A, Mortha A, Kana V, Kennard A, Ramirez JD, Rahman A, Remark R, Mogno I, Ng R, Gnjatic S, Amir ED, Solovyov A, Greenbaum B, Clemente J, Faith J, Belkaid Y, Grigg ME, Merad M (2016) Host-protozoan interactions protect from mucosal infections through activation of the inflammasome. Cell 167:444-456 e414

12. Coombes JL, Siddiqui KR, Arancibia-Carcamo CV, Hall J, Sun CM, Belkaid Y, Powrie F (2007) A functionally specialized population of mucosal CD103+ DCs induces Foxp3+ regulatory T cells via a TGF-beta and retinoic acid-dependent mechanism. J Exp Med 204:1757-1764

13. Cox MA, Jackson J, Stanton M, Rojas-Triana A, Bober L, Laverty M, Yang X, Zhu F, Liu J, Wang S, Monsma F, Vassileva G, Maguire M, Gustafson E, Bayne M, Chou CC, Lundell D, Jenh CH (2009) Short-chain fatty acids act as antiinflammatory mediators by regulating prostaglandin $\mathrm{E}(2)$ and cytokines. World $\mathrm{J}$ Gastroenterol 15:5549-5557

14. Cummings RJ, Barbet G, Bongers G, Hartmann BM, Gettler K, Muniz L, Furtado GC, Cho J, Lira SA, Blander JM (2016) Different tissue phagocytes sample apoptotic cells to direct distinct homeostasis programs. Nature 539:565-569

15. Darfeuille-Michaud A, Boudeau J, Bulois P, Neut C, Glasser AL, Barnich N, Bringer MA, Swidsinski A, Beaugerie L, Colombel JF (2004) High prevalence of adherent-invasive Escherichia coli associated with ileal mucosa in Crohn's disease. Gastroenterology 127:412-421

16. Denning TL, Norris BA, Medina-Contreras O, Manicassamy S, Geem D, Madan R, Karp CL, Pulendran B (2011) Functional specializations of intestinal dendritic cell and macrophage subsets that control Th17 and regulatory T cell responses are dependent on the T cell/APC ratio, source of mouse strain, and regional localization. J Immunol 187:733-747

17. Dunay IR, Damatta RA, Fux B, Presti R, Greco S, Colonna M, Sibley LD (2008) Gr1(+) inflammatory monocytes are required for mucosal resistance to the pathogen Toxoplasma gondii. Immunity 29:306-317

18. Epelman S, Lavine KJ, Beaudin AE, Sojka DK, Carrero JA, Calderon B, Brija T, Gautier EL, Ivanov S, Satpathy AT, Schilling JD, Schwendener R, Sergin I, Razani B, Forsberg EC, Yokoyama WM, Unanue ER, Colonna M, Randolph GJ, Mann DL (2014) Embryonic and adult-derived resident cardiac macrophages are maintained through distinct mechanisms at steady state and during inflammation. Immunity 40:91-104

19. Filardy AA, He J, Bennink J, Yewdell J, Kelsall BL (2016) Posttranscriptional control of NLRP3 inflammasome activation in colonic macrophages. Mucosal Immunol 9:850-858

20. Freire-de-Lima CG, Xiao YQ, Gardai SJ, Bratton DL, Schiemann WP, Henson PM (2006) Apoptotic cells, through transforming growth factor-beta, coordinately induce anti-inflammatory and suppress pro-inflammatory eicosanoid and $\mathrm{NO}$ synthesis in murine macrophages. J Biol Chem 281:38376-38384

21. Gabanyi I, Muller PA, Feighery L, Oliveira TY, Costa-Pinto FA, Mucida D (2016) Neuro-immune interactions drive tissue programming in intestinal macrophages. Cell 164:378-391

22. Gautier EL, Ivanov S, Lesnik P, Randolph GJ (2013) Local apoptosis mediates clearance of macrophages from resolving inflammation in mice. Blood 122:2714-2722

23. Gautier EL, Shay T, Miller J, Greter M, Jakubzick C, Ivanov S, Helft J, Chow A, Elpek KG, Gordonov S, Mazloom AR, Ma'ayan A, Chua WJ, Hansen TH, Turley SJ, Merad M, Randolph GJ, Immunological GC (2012) Gene-expression profiles and transcriptional regulatory pathways that underlie the identity and diversity of mouse tissue macrophages. Nat Immunol 13:1118-1128

24. Ginhoux F, Greter M, Leboeuf M, Nandi S, See P, Gokhan S, Mehler MF, Conway SJ, Ng LG, Stanley ER, Samokhvalov IM, Merad M (2010) Fate mapping analysis reveals that adult microglia derive from primitive macrophages. Science 330:841-845

25. Grainger JR, Wohlfert EA, Fuss IJ, Bouladoux N, Askenase MH, Legrand F, Koo LY, Brenchley JM, Fraser ID, Belkaid Y (2013) Inflammatory monocytes regulate pathologic responses to commensals during acute gastrointestinal infection. Nat Med 19: 713-721

26. Greter M, Helft J, Chow A, Hashimoto D, Mortha A, AgudoCantero J, Bogunovic M, Gautier EL, Miller J, Leboeuf M, Lu G, Aloman C, Brown BD, Pollard JW, Xiong H, Randolph GJ, Chipuk JE, Frenette PS, Merad M (2012) GM-CSF controls nonlymphoid tissue dendritic cell homeostasis but is dispensable for the differentiation of inflammatory dendritic cells. Immunity 36:1031-1046

27. Grimm MC, Pullman WE, Bennett GM, Sullivan PJ, Pavli P, Doe WF (1995) Direct evidence of monocyte recruitment to inflammatory bowel disease mucosa. J Gastroenterol Hepatol 10:387-395

28. Griseri T, McKenzie BS, Schiering C, Powrie F (2012) Dysregulated hematopoietic stem and progenitor cell activity promotes interleukin23-driven chronic intestinal inflammation. Immunity 37:1116-1129

29. Gronert K, Gewirtz A, Madara JL, Serhan CN (1998) Identification of a human enterocyte lipoxin A4 receptor that is regulated by interleukin (IL)-13 and interferon gamma and inhibits tumor necrosis factor alpha-induced IL-8 release. J Exp Med 187:1285-1294

30. Guilliams M, De Kleer I, Henri S, Post S, Vanhoutte L, De Prijck S, Deswarte K, Malissen B, Hammad H, Lambrecht BN (2013) Alveolar macrophages develop from fetal monocytes that differentiate into long-lived cells in the first week of life via GM-CSF. J Exp Med 210:1977-1992 
31. Gurung P, Li B, Subbarao Malireddi RK, Lamkanfi M, Geiger TL, Kanneganti TD (2015) Chronic TLR stimulation controls NLRP3 inflammasome activation through IL-10 mediated regulation of NLRP3 expression and caspase-8 activation. Sci Rep 5:14488

32. Hadis U, Wahl B, Schulz O, Hardtke-Wolenski M, Schippers A, Wagner N, Muller W, Sparwasser T, Forster R, Pabst O (2011) Intestinal tolerance requires gut homing and expansion of FoxP3+ regulatory T cells in the lamina propria. Immunity 34:237-246

33. Hashimoto D, Chow A, Noizat C, Teo P, Beasley MB, Leboeuf M, Becker CD, See P, Price J, Lucas D, Greter M, Mortha A, Boyer SW, Forsberg EC, Tanaka M, van Rooijen N, Garcia-Sastre A, Stanley ER, Ginhoux F, Frenette PS, Merad M (2013) Tissueresident macrophages self-maintain locally throughout adult life with minimal contribution from circulating monocytes. Immunity 38:792-804

34. Hedl M, Li J, Cho JH, Abraham C (2007) Chronic stimulation of Nod2 mediates tolerance to bacterial products. Proc Natl Acad Sci U S A 104:19440-19445

35. Heimesaat MM, Bereswill S, Fischer A, Fuchs D, Struck D, Niebergall J, Jahn HK, Dunay IR, Moter A, Gescher DM, Schumann RR, Gobel UB, Liesenfeld O (2006) Gram-negative bacteria aggravate murine small intestinal Th1-type immunopathology following oral infection with Toxoplasma gondii. J Immunol 177:8785-8795

36. Hettinger J, Richards DM, Hansson J, Barra MM, Joschko AC, Krijgsveld J, Feuerer M (2013) Origin of monocytes and macrophages in a committed progenitor. Nat Immunol 14:821-830

37. Hirotani T, Lee PY, Kuwata H, Yamamoto M, Matsumoto M, Kawase I, Akira S, Takeda K (2005) The nuclear IkappaB protein IkappaBNS selectively inhibits lipopolysaccharide-induced IL-6 production in macrophages of the colonic lamina propria. $\mathrm{J}$ Immunol 174:3650-3657

38. Hoeffel G, Chen J, Lavin Y, Low D, Almeida FF, See P, Beaudin AE, Lum J, Low I, Forsberg EC, Poidinger M, Zolezzi F, Larbi A, Ng LG, Chan JK, Greter M, Becher B, Samokhvalov IM, Merad M, Ginhoux F (2015) C-Myb(+) erythro-myeloid progenitor-derived fetal monocytes give rise to adult tissue-resident macrophages. Immunity 42:665-678

39. Hoeffel G, Wang Y, Greter M, See P, Teo P, Malleret B, Leboeuf M, Low D, Oller G, Almeida F, Choy SH, Grisotto M, Renia L, Conway SJ, Stanley ER, Chan JK, Ng LG, Samokhvalov IM, Merad M, Ginhoux F (2012) Adult Langerhans cells derive predominantly from embryonic fetal liver monocytes with a minor contribution of yolk sac-derived macrophages. J Exp Med 209: $1167-1181$

40. Hoshi N, Schenten D, Nish SA, Walther Z, Gagliani N, Flavell RA, Reizis B, Shen Z, Fox JG, Iwasaki A, Medzhitov R (2012) MyD88 signalling in colonic mononuclear phagocytes drives colitis in IL-10-deficient mice. Nat Commun 3:1120

41. Houston SA, Cerovic V, Thomson C, Brewer J, Mowat AM, Milling S (2016) The lymph nodes draining the small intestine and colon are anatomically separate and immunologically distinct. Mucosal Immunol 9:468-478

42. Hume DA, Perry VH, Gordon S (1984) The mononuclear phagocyte system of the mouse defined by immunohistochemical localisation of antigen F4/80: macrophages associated with epithelia. Anat Rec 210:503-512

43. Ingersoll MA, Spanbroek R, Lottaz C, Gautier EL, Frankenberger M, Hoffmann R, Lang R, Haniffa M, Collin M, Tacke F, Habenicht AJ, Ziegler-Heitbrock L, Randolph GJ (2010) Comparison of gene expression profiles between human and mouse monocyte subsets. Blood 115:e10-e19

44. Ivanov II, Atarashi K, Manel N, Brodie EL, Shima T, Karaoz U, Wei D, Goldfarb KC, Santee CA, Lynch SV, Tanoue T, Imaoka A, Itoh K, Takeda K, Umesaki Y, Honda K, Littman DR (2009)
Induction of intestinal Th17 cells by segmented filamentous bacteria. Cell 139:485-498

45. Jaensson E, Uronen-Hansson H, Pabst O, Eksteen B, Tian J, Coombes JL, Berg PL, Davidsson T, Powrie F, JohanssonLindbom B, Agace WW (2008) Small intestinal CD103+ dendritic cells display unique functional properties that are conserved between mice and humans. J Exp Med 205:2139-2149

46. Jung S, Aliberti J, Graemmel P, Sunshine MJ, Kreutzberg GW, Sher A, Littman DR (2000) Analysis of fractalkine receptor CX(3)CR1 function by targeted deletion and green fluorescent protein reporter gene insertion. Mol Cell Biol 20:4106-4114

47. Kabouridis PS, Lasrado R, McCallum S, Chng SH, Snippert HJ, Clevers H, Pettersson S, Pachnis V (2015) Microbiota controls the homeostasis of glial cells in the gut lamina propria. Neuron 85 : 289-295

48. Kalinski P (2012) Regulation of immune responses by prostaglandin E2. J Immunol 188:21-28

49. Kamada N, Hisamatsu T, Okamoto S, Chinen H, Kobayashi T, Sato T, Sakuraba A, Kitazume MT, Sugita A, Koganei K, Akagawa KS, Hibi T (2008) Unique CD14 intestinal macrophages contribute to the pathogenesis of Crohn disease via IL-23/IFNgamma axis. J Clin Invest 118:2269-2280

50. Kayama H, Ueda Y, Sawa Y, Jeon SG, Ma JS, Okumura R, Kubo A, Ishii M, Okazaki T, Murakami M, Yamamoto M, Yagita H, Takeda K (2012) Intestinal CX3C chemokine receptor 1(high) (CX3CR1(high)) myeloid cells prevent T-cell-dependent colitis. Proc Natl Acad Sci U S A 109:5010-5015

51. Kim KW, Vallon-Eberhard A, Zigmond E, Farache J, Shezen E, Shakhar G, Ludwig A, Lira SA, Jung S (2011) In vivo structure/ function and expression analysis of the $\mathrm{CX} 3 \mathrm{C}$ chemokine fractalkine. Blood 118:e156-e167

52. Klunker S, Chong MM, Mantel PY, Palomares O, Bassin C, Ziegler M, Ruckert B, Meiler F, Akdis M, Littman DR, Akdis CA (2009) Transcription factors RUNX1 and RUNX3 in the induction and suppressive function of Foxp3+ inducible regulatory T cells. J Exp Med 206:2701-2715

53. Konkel JE, Maruyama T, Carpenter AC, Xiong Y, Zamarron BF, Hall BE, Kulkarni AB, Zhang P, Bosselut R, Chen W (2011) Control of the development of CD8alphaalpha+ intestinal intraepithelial lymphocytes by TGF-beta. Nat Immunol 12:312319

54. Kuhn R, Lohler J, Rennick D, Rajewsky K, Muller W (1993) Interleukin-10-deficient mice develop chronic enterocolitis. Cell $75: 263-274$

55. Lavin Y, Winter D, Blecher-Gonen R, David E, Keren-Shaul H, Merad M, Jung S, Amit I (2014) Tissue-resident macrophage enhancer landscapes are shaped by the local microenvironment. Cell 159:1312-1326

56. Lee SH, Starkey PM, Gordon S (1985) Quantitative analysis of total macrophage content in adult mouse tissues. Immunochemical studies with monoclonal antibody F4/80. J Exp Med 161:475-489

57. Levy BD, Clish CB, Schmidt B, Gronert K, Serhan CN (2001) Lipid mediator class switching during acute inflammation: signals in resolution. Nat Immunol 2:612-619

58. Li B, Gurung P, Malireddi RK, Vogel P, Kanneganti TD, Geiger TL (2015) IL-10 engages macrophages to shift Th17 cytokine dependency and pathogenicity during T-cell-mediated colitis. Nat Commun 6:6131

59. Liu Y, van Kruiningen HJ, West AB, Cartun RW, Cortot A, Colombel JF (1995) Immunocytochemical evidence of Listeria, Escherichia coli, and Streptococcus antigens in Crohn's disease. Gastroenterology 108:1396-1404

60. Ludin A, Itkin T, Gur-Cohen S, Mildner A, Shezen E, Golan K, Kollet O, Kalinkovich A, Porat Z, D’Uva G, Schajnovitz A, Voronov E, Brenner DA, Apte RN, Jung S, Lapidot T (2012) Monocytes-macrophages that express alpha-smooth muscle actin 
preserve primitive hematopoietic cells in the bone marrow. Nat Immunol 13:1072-1082

61. Ma TY, Iwamoto GK, Hoa NT, Akotia V, Pedram A, Boivin MA, Said HM (2004) TNF-alpha-induced increase in intestinal epithelial tight junction permeability requires NF-kappa B activation. Am J Physiol Gastrointest Liver Physiol 286:G367-G376

62. Malvin NP, Seno H, Stappenbeck TS (2012) Colonic epithelial response to injury requires Myd88 signaling in myeloid cells. Mucosal Immunol 5:194-206

63. Manta C, Heupel E, Radulovic K, Rossini V, Garbi N, Riedel CU, Niess JH (2013) CX(3)CR1(+) macrophages support IL-22 production by innate lymphoid cells during infection with Citrobacter rodentium. Mucosal Immunol 6:177-188

64. Margolis KG, Gershon MD, Bogunovic M (2016) Cellular organization of neuroimmune interactions in the gastrointestinal tract. Trends Immunol 37:487-501

65. Mazzini E, Massimiliano L, Penna G, Rescigno M (2014) Oral tolerance can be established via gap junction transfer of fed antigens from $\mathrm{CX} 3 \mathrm{CR} 1(+)$ macrophages to $\mathrm{CD} 103(+)$ dendritic cells. Immunity 40:248-261

66. Molawi K, Wolf Y, Kandalla PK, Favret J, Hagemeyer N, Frenzel K, Pinto AR, Klapproth K, Henri S, Malissen B, Rodewald HR, Rosenthal NA, Bajenoff M, Prinz M, Jung S, Sieweke MH (2014) Progressive replacement of embryo-derived cardiac macrophages with age. J Exp Med 211:2151-2158

67. Molloy MJ, Grainger JR, Bouladoux N, Hand TW, Koo LY, Naik S, Quinones M, Dzutsev AK, Gao JL, Trinchieri G, Murphy PM, Belkaid Y (2013) Intraluminal containment of commensal outgrowth in the gut during infection-induced dysbiosis. Cell Host Microbe 14:318-328

68. Mortha A, Chudnovskiy A, Hashimoto D, Bogunovic M, Spencer SP, Belkaid Y, Merad M (2014) Microbiota-dependent crosstalk between macrophages and ILC3 promotes intestinal homeostasis. Science 343:1249288

69. Muller PA, Koscso B, Rajani GM, Stevanovic K, Berres ML, Hashimoto D, Mortha A, Leboeuf M, Li XM, Mucida D, Stanley ER, Dahan S, Margolis KG, Gershon MD, Merad M, Bogunovic M (2014) Crosstalk between muscularis macrophages and enteric neurons regulates gastrointestinal motility. Cell 158: 300-313

70. Nagashima R, Maeda K, Imai Y, Takahashi T (1996) Lamina propria macrophages in the human gastrointestinal mucosa: their distribution, immunohistological phenotype, and function. J Histochem Cytochem 44:721-731

71. Niess JH, Adler G (2010) Enteric flora expands gut lamina propria CX3CR1+ dendritic cells supporting inflammatory immune responses under normal and inflammatory conditions. J Immunol 184:2026-2037

72. Niess JH, Brand S, Gu X, Landsman L, Jung S, McCormick BA, Vyas JM, Boes M, Ploegh HL, Fox JG, Littman DR, Reinecker HC (2005) CX3CR1-mediated dendritic cell access to the intestinal lumen and bacterial clearance. Science 307:254-258

73. Oldenhove G, Bouladoux N, Wohlfert EA, Hall JA, Chou D, Dos Santos L, O'Brien S, Blank R, Lamb E, Natarajan S, Kastenmayer R, Hunter C, Grigg ME, Belkaid Y (2009) Decrease of Foxp3+ Treg cell number and acquisition of effector cell phenotype during lethal infection. Immunity 31:772-786

74. Panea C, Farkas AM, Goto Y, Abdollahi-Roodsaz S, Lee C, Koscso B, Gowda K, Hohl TM, Bogunovic M, Ivanov II (2015) Intestinal monocyte-derived macrophages control commensalspecific Th17 responses. Cell Rep 12:1314-1324

75. Pender SL, Quinn JJ, Sanderson IR, MacDonald TT (2000) Butyrate upregulates stromelysin-1 production by intestinal mesenchymal cells. Am J Physiol Gastrointest Liver Physiol 279: G918-G924
76. Pereira CF, Boven LA, Middel J, Verhoef J, Nottet HS (2000) Induction of cyclooxygenase-2 expression during HIV-1-infected monocyte-derived macrophage and human brain microvascular endothelial cell interactions. J Leukoc Biol 68:423-428

77. Pull SL, Doherty JM, Mills JC, Gordon JI, Stappenbeck TS (2005) Activated macrophages are an adaptive element of the colonic epithelial progenitor niche necessary for regenerative responses to injury. Proc Natl Acad Sci U S A 102:99-104

78. Rani R, Smulian AG, Greaves DR, Hogan SP, Herbert DR (2011) TGF-beta limits IL-33 production and promotes the resolution of colitis through regulation of macrophage function. Eur J Immunol 41:2000-2009

79. Rivollier A, He J, Kole A, Valatas V, Kelsall BL (2012) Inflammation switches the differentiation program of Ly6Chi monocytes from antiinflammatory macrophages to inflammatory dendritic cells in the colon. J Exp Med 209:139-155

80. Rugtveit J, Haraldsen G, Hogasen AK, Bakka A, Brandtzaeg P, Scott H (1995) Respiratory burst of intestinal macrophages in inflammatory bowel disease is mainly caused by CD14+L1+ monocyte derived cells. Gut 37:367-373

81. Rugtveit J, Nilsen EM, Bakka A, Carlsen H, Brandtzaeg P, Scott H (1997) Cytokine profiles differ in newly recruited and resident subsets of mucosal macrophages from inflammatory bowel disease. Gastroenterology 112:1493-1505

82. Ryan GR, Dai XM, Dominguez MG, Tong W, Chuan F, Chisholm O, Russell RG, Pollard JW, Stanley ER (2001) Rescue of the colony-stimulating factor 1 (CSF-1)-nullizygous mouse (Csfl(op)/Csfl(op)) phenotype with a CSF-1 transgene and identification of sites of local CSF-1 synthesis. Blood 98:74-84

83. Schlitzer A, McGovern N, Teo P, Zelante T, Atarashi K, Low D, Ho AW, See P, Shin A, Wasan PS, Hoeffel G, Malleret B, Heiseke A, Chew S, Jardine L, Purvis HA, Hilkens CM, Tam J, Poidinger M, Stanley ER, Krug AB, Renia L, Sivasankar B, Ng LG, Collin M, Ricciardi-Castagnoli P, Honda K, Haniffa M, Ginhoux F (2013) IRF4 transcription factor-dependent CD11b+ dendritic cells in human and mouse control mucosal IL-17 cytokine responses. Immunity 38:970-983

84. Schridde A, Bain CC, Mayer JU, Montgomery J, Pollet E, Denecke B, Milling SW, Jenkins SJ, Dalod M, Henri S, Malissen B, Pabst O, and McL Mowat A. Tissue-specific differentiation of colonic macrophages requires TGFbeta receptormediated signaling. Mucosal immunology 2017.

85. Schulz O, Jaensson E, Persson EK, Liu X, Worbs T, Agace WW, Pabst O (2009) Intestinal CD103+, but not CX3CR1+, antigen sampling cells migrate in lymph and serve classical dendritic cell functions. J Exp Med 206:3101-3114

86. Scott CL, Henri S, Guilliams M (2014) Mononuclear phagocytes of the intestine, the skin, and the lung. Immunol Rev 262:9-24

87. Scott CL, Zheng F, De Baetselier P, Martens L, Saeys Y, De Prijck S, Lippens S, Abels C, Schoonooghe S, Raes G, Devoogdt N, Lambrecht BN, Beschin A, Guilliams M (2016) Bone marrowderived monocytes give rise to self-renewing and fully differentiated Kupffer cells. Nat Commun 7:10321

88. Seo SU, Kuffa P, Kitamoto S, Nagao-Kitamoto H, Rousseau J, Kim YG, Nunez G, Kamada N (2015) Intestinal macrophages arising from CCR2(+) monocytes control pathogen infection by activating innate lymphoid cells. Nat Commun 6:8010

89. Serbina NV, Pamer EG (2006) Monocyte emigration from bone marrow during bacterial infection requires signals mediated by chemokine receptor CCR2. Nat Immunol 7:311-317

90. Serbina NV, Salazar-Mather TP, Biron CA, Kuziel WA, Pamer EG (2003) TNF/iNOS-producing dendritic cells mediate innate immune defense against bacterial infection. Immunity 19:59-70

91. Serhan CN, Chiang N, Van Dyke TE (2008) Resolving inflammation: dual anti-inflammatory and pro-resolution lipid mediators. Nat Rev Immunol 8:349-361 
92. Shan M, Gentile M, Yeiser JR, Walland AC, Bornstein VU, Chen $\mathrm{K}$, He B, Cassis L, Bigas A, Cols M, Comerma L, Huang B, Blander JM, Xiong H, Mayer L, Berin C, Augenlicht LH, Velcich A, Cerutti A (2013) Mucus enhances gut homeostasis and oral tolerance by delivering immunoregulatory signals. Science 342:447-453

93. Shaw MH, Kamada N, Kim YG, Nunez G (2012) Microbiotainduced IL-1beta, but not IL-6, is critical for the development of steady-state TH17 cells in the intestine. J Exp Med 209:251-258

94. Shouval DS, Biswas A, Goettel JA, McCann K, Conaway E, Redhu NS, Mascanfroni ID, Al Adham Z, Lavoie S, Ibourk M, Nguyen DD, Samsom JN, Escher JC, Somech R, Weiss B, Beier R, Conklin LS, Ebens CL, Santos FG, Ferreira AR, Sherlock M, Bhan AK, Muller W, Mora JR, Quintana FJ, Klein C, Muise AM, Horwitz BH, Snapper SB (2014) Interleukin-10 receptor signaling in innate immune cells regulates mucosal immune tolerance and anti-inflammatory macrophage function. Immunity 40:706-719

95. Smith PD, Smythies LE, Shen R, Greenwell-Wild T, Gliozzi M, Wahl SM (2011) Intestinal macrophages and response to microbial encroachment. Mucosal Immunol 4:31-42

96. Smythies LE, Sellers M, Clements RH, Mosteller-Barnum M, Meng G, Benjamin WH, Orenstein JM, Smith PD (2005) Human intestinal macrophages display profound inflammatory anergy despite avid phagocytic and bacteriocidal activity. J Clin Invest 115:66-75

97. Smythies LE, Shen R, Bimczok D, Novak L, Clements RH, Eckhoff DE, Bouchard P, George MD, Hu WK, Dandekar S, Smith PD (2010) Inflammation anergy in human intestinal macrophages is due to Smad-induced IkappaBalpha expression and NF-kappaB inactivation. J Biol Chem 285:19593-19604

98. Soroosh P, Doherty TA, Duan W, Mehta AK, Choi H, Adams YF, Mikulski Z, Khorram N, Rosenthal P, Broide DH, Croft M (2013) Lung-resident tissue macrophages generate Foxp3+ regulatory $\mathrm{T}$ cells and promote airway tolerance. J Exp Med 210:775-788

99. Stadnyk AW (1994) Cytokine production by epithelial cells. FASEB J 8:1041-1047

100. Sun CM, Hall JA, Blank RB, Bouladoux N, Oukka M, Mora JR, Belkaid Y (2007) Small intestine lamina propria dendritic cells promote de novo generation of Foxp3 T reg cells via retinoic acid. J Exp Med 204:1775-1785

101. Suzuki T, Arumugam P, Sakagami T, Lachmann N, Chalk C, Sallese A, Abe S, Trapnell C, Carey B, Moritz T, Malik P, Lutzko C, Wood RE, Trapnell BC (2014) Pulmonary macrophage transplantation therapy. Nature 514:450-454

102. Takeda K, Clausen BE, Kaisho T, Tsujimura T, Terada N, Forster I, Akira S (1999) Enhanced Th1 activity and development of chronic enterocolitis in mice devoid of Stat3 in macrophages and neutrophils. Immunity 10:39-49

103. Tamoutounour S, Guilliams M, Montanana Sanchis F, Liu H, Terhorst D, Malosse C, Pollet E, Ardouin L, Luche H, Sanchez C, Dalod M, Malissen B, Henri S (2013) Origins and functional specialization of macrophages and of conventional and monocytederived dendritic cells in mouse skin. Immunity 39:925-938

104. Tamoutounour S, Henri S, Lelouard H, de Bovis B, de Haar C, van der Woude CJ, Woltman AM, Reyal Y, Bonnet D, Sichien D, Bain CC, Mowat AM, Reis e Sousa C, Poulin LF, Malissen B, Guilliams M (2012) CD64 distinguishes macrophages from dendritic cells in the gut and reveals the Th1-inducing role of mesenteric lymph node macrophages during colitis. Eur J Immunol 42: 3150-3166

105. Thiesen S, Janciauskiene S, Uronen-Hansson H, Agace W, Hogerkorp CM, Spee P, Hakansson K, Grip O (2014)
CD14(hi)HLA-DR(dim) macrophages, with a resemblance to classical blood monocytes, dominate inflamed mucosa in Crohn's disease. J Leukoc Biol 95:531-541

106. Trompette A, Gollwitzer ES, Yadava K, Sichelstiel AK, Sprenger N, Ngom-Bru C, Blanchard C, Junt T, Nicod LP, Harris NL, Marsland BJ (2014) Gut microbiota metabolism of dietary fiber influences allergic airway disease and hematopoiesis. Nat Med 20: $159-166$

107. Ubeda C, Lipuma L, Gobourne A, Viale A, Leiner I, Equinda M, Khanin R, Pamer EG (2012) Familial transmission rather than defective innate immunity shapes the distinct intestinal microbiota of TLR-deficient mice. J Exp Med 209:1445-1456

108. Ueda Y, Kayama H, Jeon SG, Kusu T, Isaka Y, Rakugi H, Yamamoto M, Takeda K (2010) Commensal microbiota induce LPS hyporesponsiveness in colonic macrophages via the production of IL-10. Int Immunol 22:953-962

109. van de Laar L, Saelens W, De Prijck S, Martens L, Scott CL, Van Isterdael G, Hoffmann E, Beyaert R, Saeys Y, Lambrecht BN, Guilliams M (2016) Yolk sac macrophages, fetal liver, and adult monocytes can colonize an empty niche and develop into functional tissue-resident macrophages. Immunity 44:755-768

110. van Furth R, Cohn ZA, Hirsch JG, Humphrey JH, Spector WG, Langevoort HL (1972) The mononuclear phagocyte system: a new classification of macrophages, monocytes, and their precursor cells. Bull World Health Organ 46:845-852

111. Varol C, Vallon-Eberhard A, Elinav E, Aychek T, Shapira Y, Luche H, Fehling HJ, Hardt WD, Shakhar G, Jung S (2009) Intestinal lamina propria dendritic cell subsets have different origin and functions. Immunity 31:502-512

112. Wang Y, Szretter KJ, Vermi W, Gilfillan S, Rossini C, Cella M, Barrow AD, Diamond MS, Colonna M (2012) IL-34 is a tissuerestricted ligand of CSF1R required for the development of Langerhans cells and microglia. Nat Immunol 13:753-760

113. Weaver CT, Elson CO, Fouser LA, Kolls JK (2013) The Th17 pathway and inflammatory diseases of the intestines, lungs, and skin. Annu Rev Pathol 8:477-512

114. Weber B, Saurer L, Schenk M, Dickgreber N, Mueller C (2011) CX3CR1 defines functionally distinct intestinal mononuclear phagocyte subsets which maintain their respective functions during homeostatic and inflammatory conditions. Eur J Immunol 41: 773-779

115. Wertheim WA, Kunkel SL, Standiford TJ, Burdick MD, Becker FS, Wilke CA, Gilbert AR, Strieter RM (1993) Regulation of neutrophil-derived IL-8: the role of prostaglandin E2, dexamethasone, and IL-4. J Immunol 151:2166-2175

116. Yona S, Kim KW, Wolf Y, Mildner A, Varol D, Breker M, StraussAyali D, Viukov S, Guilliams M, Misharin A, Hume DA, Perlman H, Malissen B, Zelzer E, Jung S (2013) Fate mapping reveals origins and dynamics of monocytes and tissue macrophages under homeostasis. Immunity 38:79-91

117. Zigmond E, Bernshtein B, Friedlander G, Walker CR, Yona S, Kim KW, Brenner O, Krauthgamer R, Varol C, Muller W, Jung S (2014) Macrophage-restricted interleukin-10 receptor deficiency, but not IL-10 deficiency, causes severe spontaneous colitis. Immunity 40:720-733

118. Zigmond E, Jung S (2013) Intestinal macrophages: well educated exceptions from the rule. Trends Immunol 34:162-168

119. Zigmond E, Varol C, Farache J, Elmaliah E, Satpathy AT, Friedlander G, Mack M, Shpigel N, Boneca IG, Murphy KM, Shakhar G, Halpern Z, Jung S (2012) Ly6C hi monocytes in the inflamed colon give rise to proinflammatory effector cells and migratory antigen-presenting cells. Immunity 37:1076-1090 